\title{
Single factors direct the differentiation of stem cells from the fetal and adult central nervous system
}

\author{
Karl K. Johe, Thomas G. Hazel, Thomas Muller, Millicent M. Dugich-Djordjevic, \\ and Ronald D.G. McKay ${ }^{1}$
}

Laboratory of Molecular Biology, National Institute of Neurological Disorders and Stroke, National Institutes of Health, Bethesda, Maryland 20892 USA

\begin{abstract}
Identifying the signals that regulate stem cell differentiation is fundamental to understanding cellular diversity in the brain. In this paper we identify factors that act in an instructive fashion to direct the differentiation of multipotential stem cells derived from the embryonic central nervous system (CNS). CNS stem cell clones differentiate to multiple fates: neurons, astrocytes, and oligodendrocytes. The differentiation of cells in a clone is influenced by extracellular signals: Platelet-derived growth factor (PDGF-AA, -AB, and -BB) supports neuronal differentiation. In contrast, ciliary neurotrophic factor and thyroid hormone T3 act instructively on stem cells to generate clones of astrocytes and oligodendrocytes, respectively. Adult stem cells had remarkably similar responses to these growth factors. These results support a simple model in which transient exposure to extrinsic factors acting through known pathways initiates fate decisions by multipotential CNS stem cells.
\end{abstract}

[Key Words: Stem cells; neurons; glia]

Received August 9, 1996; revised version accepted October 29, 1996.

Most of the neuronal and glial cell types found in the mature central nervous system originate from precursor cells in the ventricular zone of the fetal brain and spinal cord (Jacobson 1991). Recently, several studies have examined cell lineage in the vertebrate central nervous system (CNS) to see whether neuronal and glial cell types originate from a common precursor or from distinct progenitors (Kornack and Rakic 1995; Reid et al. 1995; for review, see Luskin 1994). In cortex (Price and Thurlow 1988; Walsh and Cepko 1988), retina (Turner and Cepko 1987; Holt et al. 1988; Wetts and Fraser 1988), and optic tectum (Galileo et al. 1990), a single precursor cell can give rise to both neurons and glia as well as different types of neurons even at late stages of neurogenesis. These results imply that multipotential precursors persisting throughout CNS development differentiate in response to local cues.

At the same time, other lineage analyses using retroviral marking indicated that separate progenitors give rise to neurons and glia as well as to neuronal subtypes, suggesting that those cells are committed to a particular fate through multiple cell divisions (Parnavelas et al. 1991; Luskin et al. 1993; Mione et al. 1994). Thus, the results from in vivo lineage analysis are not uniform. It is generally acknowledged that extrinsic factors must be

${ }^{1}$ Corresponding author. important in generating the cellular diversity observed in the CNS (Ferri and Levitt 1995; Lillien 1995). However, heritable intrinsic determination of cell fates before mitosis is complete is also a key component of current hypotheses of mammalian CNS development /Chenn and McConnell 1995; Kornack and Rakic 1995; Soriano et al. 1995; Reid et al. 1995). The relative roles of extracellular signals and cell autonomous mechanisms regulating fate choice are not well understood.

Most lineage studies in the mammalian CNS have focused on mapping the actual fate of cells in specific environments in vivo. Fate maps do not contain information about the potential of the cells; thus, in vivo lineage analysis neither identifies the precursor cells nor defines the mechanism driving them to specific fates. To explore the developmental mechanisms that control the specification, determination, and potency of cells, they must be manipulated and not simply labeled. The developmental capacity of a given precursor cell can be tested directly by transplantation in vivo or by manipulating its environment in tissue culture. Results from transplantation experiments have demonstrated the plasticity of neuronal precursors by showing that cells from a single region can give rise to neurons appropriate to ectopic regions of the host brain (Brustle et al. 1995; Fishell 1995; VicarioAbejon et al. 1995a).

Several in vitro approaches have been used to analyze the lineage of cells in the CNS. In vitro experiments have 
defined a bipotential precursor with the capacity to differentiate into either oligodendrocytes or type 2 astrocytes (Raff et al. 1983; for review, see Barres and Raff 1994). Mitotic cells from acutely dissociated embryonic cortex and hippocampus have been analyzed by retroviral labeling. Clones ranging from a single cell type to variable mixtures of neurons, astrocytes, and oligodendrocytes were observed (Williams et al. 1991; Gotz et al. 1995; Williams and Price 1995). Clones of proliferative cells from the embryonic brain have been analyzed for their differentiation capacity in a short-term microculture system and have provided additional evidence for multipotential stem cells in the CNS (Temple 1989; Davis and Temple 1994). Other types of precursor cells from developing and adult CNS have been expanded in longer term culture by the mitogenic actions of basic fibroblast growth factor (bFGF) or epidermal growth factor (EGF) (for review, see Gage et al. 1995; Kilpatrick et al. 1995; Temple and Qian 1996). However, although the differentiation potential of various neural precursors expanded in vitro have been explored previously, there are few examples of a systematic clonal analysis that is necessary to fully characterize the mechanisms that regulate the origin of neurons and glia.

To further explore the origin of cell types in the vertebrate CNS, we established an in vitro system that permits extensive proliferation and controlled differentiation of nestin-positive cells from different regions of the fetal brain. Quantitative clonal analysis reveals that cells expanded for up to 1 month maintain the capacity to differentiate into all three major cell types of the mature CNS: neurons, astrocytes, and oligodendrocytes. Defined extracellular factors act in an instructive mode to restrict the differentiation potential of these CNS stem cells to unipotenital progenitors for either astrocytes or oligodendrocytes. Furthermore, we find that multipotential stem cells with similar responses to growth factors are present in the adult brain. These results suggest that the action of distinct extrinsic signals acting on a single class of multipotential stem cell is a central mechanism in the origin of cell types in the brain.

\section{Results \\ Mitogen withdrawal initiates the differentiation of expanded CNS cells}

Hippocampal cells isolated from embryonic rat brains were expanded by daily addition of bFGF in serum-free medium. A continuous supply of bFGF was important to repress differentiation and to maintain a homogeneous population of rapidly dividing cells expressing nestin, an intermediate filament protein characteristic for CNS precursor cells (Lendahl et al. 1990). Less than 1\% of the cells expressed neuronal antigens, the astroglial marker GFAP or the oligodendroglial markers $\mathrm{O} 4$ and GalC. Withdrawal of bFGF initiated differentiation within 24 hr. Over a 6-day period, there was a progressive increase in the number of cells expressing several well-established neuron-specific antigens, including MAP2a, MAP2b and MAP2c, $\beta$-tubulin type III (TuJ1), tau, and neurofilaments (NFs) L, M, and $\mathrm{H}$ (Fig. 1A). Up to $50 \%$ of these cells expressed the neuronal antigens and exhibited a complex neuronal morphology. Varying proportions of the neurons were immunopositive for neuronal markers such as GABA, glutamate, calretinin, and calbindin (data not shown). Specific subtypes of GABA and glutamate receptors known to be present in the embryonic brain (Laurie et al. 1992; Bochet al. 1994; Monyer et al. 1994) were also expressed in the differentiated cells (Fig. 1B). These results demonstrate that the long-term expanded cells differentiate efficiently to generate neurons. The remaining $50 \%$ of the differentiated cells expressed GFAP, GalC/O4, or nestin (data not shown). Al-

Figure 1. $(A)$ Controlled differentiation of CNS stem cells at high density. Rapidly dividing nestin-positive precursor cells after 12 days in bFGF (10 $\mathrm{ng} / \mathrm{ml}$ ) were labeled with 10 $\mu \mathrm{M}$ BrdU during the last $24 \mathrm{hr}$ of proliferation. Differentiation was then initiated by withdrawal of bFGF (day 0) and continued for up to 6 days. At indicated times, cells were fixed and stained for BrdU and various neuronal antigens. Ratio of cells double-stained for BrdU and each neuronal antigen to total $\mathrm{BrdU}+$ cells per $40 \times$ field are shown. Up to $50 \%$ of BrdU + cells expressed neuronal antigens, and their expression was time dependent. MAP2 + ; (shaded diamond) Tul1+; ( $\square$ ) NF$\mathrm{L}+;(\mathbf{A}) \mathrm{NF}-\mathrm{M}+$. (B) RT-PCR analysis of gene expression in undifferentiated and differenti-

A

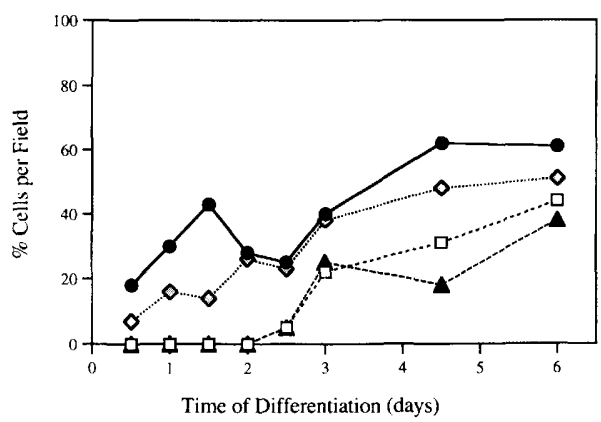

B

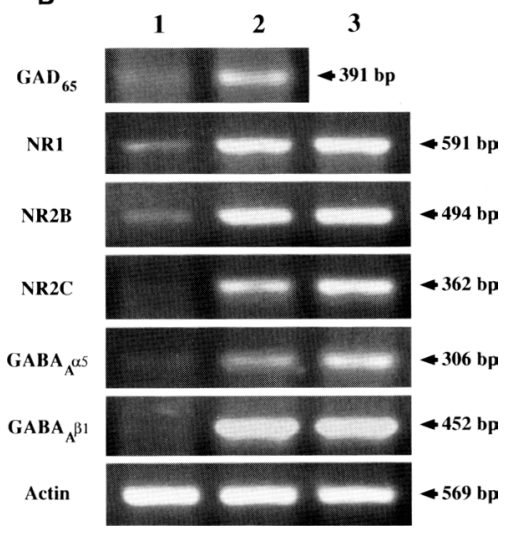
ated cultured CNS stem cells. Total RNA isolated from undifferentiated stem cells (lane 1) or stem cells that had been differentiated for 6 days (lane 2) or 12 days (lane 3) was reverse-transcribed and analyzed by PCR as described in Materials and Methods. As indicated at left, oligonucleotides corresponding to the following gene products were used: glutamate decarboxylase $\left(\mathrm{GAD}_{65}\right)$; the $\mathrm{NMDA}$

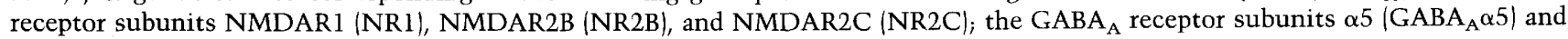
$\beta 1\left(\mathrm{GABA}_{\mathrm{A}} \beta 1\right)$; and actin. The molecular mass of the PCR products is indicated at right. 
though neurons and glia have been observed previously in expanded culture, these experiments establish that the differentiation of proliferating precursor cells to neurons and glia can be initiated at a precise time point and thus permit large-scale lineage analysis in vitro.

\section{Multipotentiality of CNS precursor cells}

To determine whether the precursor population contains separate committed progenitors that independently give rise to neurons and glia, rapidly dividing cells were plated at clonal density ( 200 cells per $10-\mathrm{cm}$ plate) and well-isolated single cells were marked with 3-mm-diameter circles (Fig. 2A). Five to ten percent of the marked single cells survived and proliferated with a doubling time of $24 \mathrm{hr}$ to generate clones of nestin-positive cells (Fig. 2B). After various periods of expansion (clone sizes ranging from $2^{4}$ to $2^{10}$ cells), clones were differentiated by withdrawing bFGF and further cultured in serum-free medium without bFGF for 6 days. During the period after mitogen withdrawal, heterogeneous morphologies appeared rapidly and neurons differentiated in the clones (Fig. 2C,D). As in high-density culture, $50 \%$ of the cells in a clone expressed neuronal antigens including MAP2, tau, and $\beta$-tubulin type III (Table 1A). Neurofilament expression was delayed under these conditions, most likely owing to the low cell density. Other cell types within clones were analyzed by double-staining with combinations of cell type-specific antibodies. Eight percent of cells in the clones expressed GFAP and displayed a characteristic astrocytic morphology (Table 1A; Fig. 3A,C). In addition, $8 \%$ of the cells in the clones were GalC + and had typical oligodendrocyte morphology (Table 1A; Fig. 3C). The remaining cells were unstained by any of the antibodies specific for differentiated cell types but reacted with A2B5 and/or antinestin antibodies that stain dividing precursors. A maximum of $20 \%$ of the cells died during differentiation. Almost all clones ana- lyzed contained highly reproducible numbers of neurons, oligodendrocytes, and astrocytes.

Prior to differentiation, cells within clones displayed a uniform morphology and were immunonegative for antigens other than nestin. Yet, the separation of neuronal and non-neuronal morphologies occurred rapidly within $24 \mathrm{hr}$ and only after mitogen withdrawal. The early neurons were evenly distributed throughout the clone without obvious polarity or localization, suggesting the $a b$ sence of committed neuronal progenitors during clonal expansion. Moreover, the number of neurons increased linearly with increasing clone size and reproducibly constituted $50 \%$ of the clone (Fig. 4A,B). A very high proportion of clones were multipotential whether cells were obtained from acutely dissociated cells with no prior passage or from cells after four passages ( 26 days of expansion) (Table 1A). This finding shows that the multipotentiality of these cells is stable in culture. Furthermore, the absence of clones consisting of a single cell type shows that under these conditions committed progenitor cells are absent.

To further determine whether expanding clones consisted of distinct proliferating committed progenitors, individual clones were picked, dissociated, and replated again as single cells in the presence of bFGF. Ten to fifteen percent of the cells gave rise to second generation clones. After bFGF withdrawal, almost all of the subclones contained neurons, astrocytes, oligodendrocytes, and unstained cells (Table 1B). No subclone consisted of only one cell type. These data suggest strongly that, during the clonal expansion, the multipotential cells undergo symmetric divisions to generate daughter cells with multipotential capacity and are therefore stem cells.

\section{Stem cells are abundant in the fetal brain}

Cells with multipotential capacity were found through-
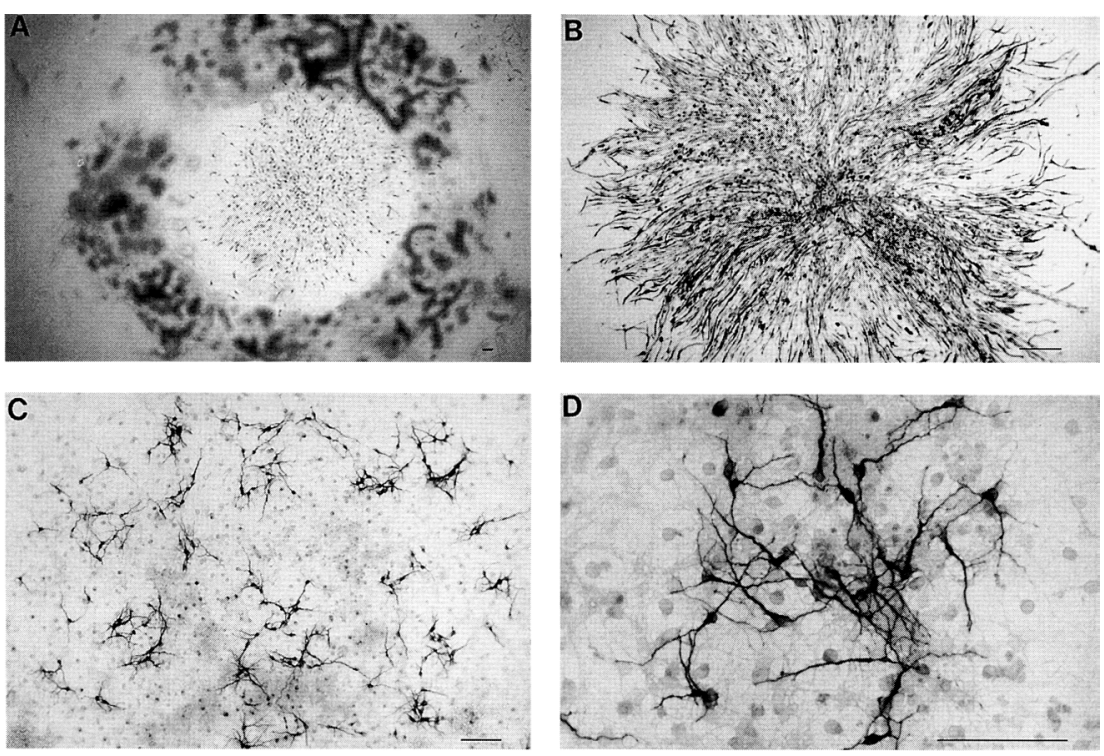

Figure 2. Clonal expansion and differentiation of CNS stem cells. (A) An example of a clone marked at a single-cell stage by a circle and subsequently expanded to large size and immunostained. (B) A typical clone expanded for 10 days, fixed without differentiation, and stained with antinestin antibody. Note the uniform radial morphology of the cells. $(C)$ A typical clone after 6 days of differentiation, immunostained with neuron-specific antitubulin $\beta$ III $(T u I 1)$ antibody. $(D)$ Higher magnification view of $\mathrm{TuJ} 1+$ neurons in the same clone shown in $C$. 
Johe et al.

Table 1. Cell type composition of differentiated clones

\begin{tabular}{|c|c|c|c|c|c|c|c|c|c|}
\hline \multicolumn{5}{|c|}{ A. Clones of embryonic hippocampal stem cells ${ }^{\mathbf{a}}$} & \multicolumn{5}{|c|}{$\begin{array}{l}\text { B. Subclones from embryonic hippocampal stem cells }{ }^{c} \\
\text { (continued) }\end{array}$} \\
\hline Passage & $\begin{array}{l}\text { Clone } \\
\text { size }\end{array}$ & $\mathrm{MAP} 2+|\%|$ & GalC $+(\%)$ & GFAP $+(\%)$ & Subclone & $\begin{array}{l}\text { Clone } \\
\text { size }\end{array}$ & $\mathrm{MAP} 2+(\%)$ & Galc $+|\%|$ & GFAP $+\{\% \mid$ \\
\hline 1 & 319 & $145 \mid 45)$ & & $41(13)$ & Hl8.6 & 402 & $26(6)$ & $75(19)$ & \\
\hline 1 & 451 & $245(54)$ & & $0(0)$ & $\mathrm{H} 18.7$ & 554 & & $49(9)$ & $45(8)$ \\
\hline 1 & 1237 & $634(51)$ & & $9(1)$ & $\mathrm{H} 18.7$ & 554 & & $49\{9\}$ & $45(8)$ \\
\hline 1 & 2197 & $956(44)$ & & $42(2)$ & $\mathrm{Hl} 8.8$ & 571 & & $23|4|$ & $49(9)$ \\
\hline 1 & 2779 & $1617(58)$ & & $336(12)$ & H18.9 & 662 & & $41|6\rangle$ & $118(18)$ \\
\hline 4 & 71 & & $10(14)$ & $5(7)$ & $\mathrm{H} 18.10$ & 669 & $46(7)$ & $46(7)$ & \\
\hline 4 & 139 & & $14(10)$ & $4(3)$ & $\mathrm{H} 18.11$ & 827 & $57(7)$ & $18(2)$ & \\
\hline 4 & 296 & & $21(7)$ & $139(47)$ & $\mathrm{H} 18.12$ & 836 & $92(11)$ & $97(12)$ & \\
\hline 4 & 341 & & $54(16)$ & $38(11)$ & $\mathrm{H} 18.13$ & 1084 & $104(10)$ & $53|5|$ & \\
\hline 4 & 420 & & $39(9)$ & $25(6)$ & $\mathrm{H} 18.14$ & 1268 & $124(10)$ & $163(13)$ & \\
\hline 4 & 600 & & $35(6)$ & $60(10)$ & H18.15 & 1284 & $75|6|$ & $193(15)$ & \\
\hline 4 & 662 & & $66(10)$ & $62(9)$ & & & & & \\
\hline 4 & 141 & $42(30)$ & $4(3)$ & & Average $^{d}$ & & $20.1 \pm 1.4 \%$ & $8.9 \pm 1.1 \%$ & $10.0 \pm 0.7 \%$ \\
\hline $\begin{array}{l}4 \\
4\end{array}$ & $\begin{array}{l}427 \\
610\end{array}$ & $\begin{array}{l}220(52) \\
306(50)\end{array}$ & $\begin{array}{l}15|4| \\
29|5|\end{array}$ & & & d & 15 & & \\
\hline
\end{tabular}

\begin{tabular}{llll} 
Average $^{\mathrm{b}}$ & $48.6 \pm 1.6 \%$ & $8.4 \pm 1.0 \%$ & $7.8 \pm 2.3 \%$ \\
\hline
\end{tabular}

B. Subclones from embryonic hippocampal stem cells ${ }^{c}$

\begin{tabular}{lrccc} 
Subclone & $\begin{array}{c}\text { Clone } \\
\text { size }\end{array}$ & MAP2 $+(\%)$ & Galc $+(\%)$ & GFAP $+(\%)$ \\
\hline H16.1 & 337 & $22(7)$ & $99(129)$ & \\
H16.2 & 338 & $13(4)$ & $157(46)$ & \\
H16.3 & 537 & $132(25)$ & $48(9)$ & \\
H16.4 & 565 & $98(17)$ & $28(5)$ & \\
H16.5 & 831 & $96(12)$ & $107(13)$ & \\
H16.6 & 886 & $158(18)$ & $134(15)$ & \\
H16.7 & 893 & $135(15)$ & $66(7)$ & \\
H16.8 & 950 & $154(16)$ & $53(6)$ & \\
H16.9 & 951 & $112(12)$ & $120(13)$ & \\
H16.10 & 970 & $105(11)$ & $95(10)$ & \\
H19.1 & 84 & $11(13)$ & & $0(0)$ \\
H19.2 & 211 & $45(21)$ & & $0(00)$ \\
H19.3 & 363 & $61(17)$ & & $18(5)$ \\
H19.4 & 697 & $172(25)$ & & $5(1)$ \\
H19.5 & 861 & $135(16)$ & & $123(8)$ \\
H19.6 & 1469 & $401(27)$ & & $179(10)$ \\
H19.7 & 1841 & $486(26)$ & & $0(0)$ \\
H18.1 & 88 & & $4(15)$ & $0(0)$ \\
H18.2 & 104 & & $3(3)$ & $119(31)$ \\
H18.3 & 193 & & $16(8)$ & \\
H18.4 & 237 & $14(6)$ & $39(16)$ & $65(17)$ \\
H18.5 & 384 & & & $119)$ \\
\hline
\end{tabular}

\begin{tabular}{lcccc} 
Passage & $\begin{array}{c}\text { Clone } \\
\text { size }\end{array}$ & MAP2 $+(\%)$ & GalC $+(\%)$ & GFAP $+(\%)$ \\
\hline 1 & 73 & $6(8)$ & & $37(51)$ \\
1 & 159 & $56(35)$ & & $42(26)$ \\
1 & 173 & $57(33)$ & & $26(15)$ \\
1 & 185 & $71(38)$ & & $32(17)$ \\
1 & 230 & $97(42)$ & & $39(17)$ \\
1 & 273 & $139(51)$ & & $56(21)$ \\
1 & 387 & $117(30)$ & & $45(12)$ \\
1 & 554 & $237(43)$ & & $84(15)$ \\
1 & 675 & $280(41)$ & & $74(11)$ \\
1 & 847 & $399(47)$ & & $155(18)$ \\
1 & 496 & & $23(5)$ & $92(19)$ \\
1 & 526 & & $715(22)$ \\
1 & 644 & & $19(3)$ & $26(4)$ \\
1 & 713 & & $22(3)$ & $179(25)$ \\
1 & 1112 & & $56(5)$ & $235(21)$ \\
0 & 278 & $153(55)$ & $6(2)$ & \\
0 & 305 & $145(48)$ & $19(6)$ & \\
1 & 411 & $156(38)$ & $68(17)$ & \\
0 & 513 & $242(47)$ & $3(1)$ & \\
0 & 532 & $246(46)$ & $26(5)$ & \\
0 & 538 & $283(53)$ & $10(2)$ & \\
0 & 584 & $277(47)$ & $32(5)$ & \\
0 & 1012 & $498(49)$ & $5(0)$ & \\
& & & & \\
Average & & $41.7 \pm 2.6 \%$ & $4.2 \pm 1.2 \%$ & $19.6 \pm 2.7 \%$ \\
\hline
\end{tabular}

${ }^{a}$ A partial list of typical clones are presented. Clone size was determined by counting total number of cells in each clone. The numbers of cells stained positive for each of the three cell-type specific antigens are shown and their relative proportions are in parenthesis. A total of 48 clones was quantified from four different passages in six separate experiments.

${ }^{b}$ Average indicates the average composition of each cell type in the 48 clones.

${ }^{\mathrm{c}} \mathrm{A}$ total of 84 subclones were quantified from 13 independent parental clones in two separate experiments. Representative subclones

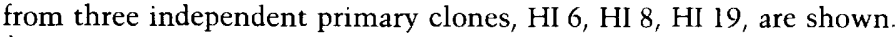

${ }^{\mathrm{d}}$ Average composition of each cell type from the 84 subclones.

out the developing neuroepithelium. Under identical culture conditions, similar cells could be prepared from other regions of the developing CNS including the cere- bral cortex, striatum, septum, diencephalon, mesencephalon, hindbrain, and spinal cord (data not shown). From embryonic day 14 (E14) cortex and striatum and E16 hip- 


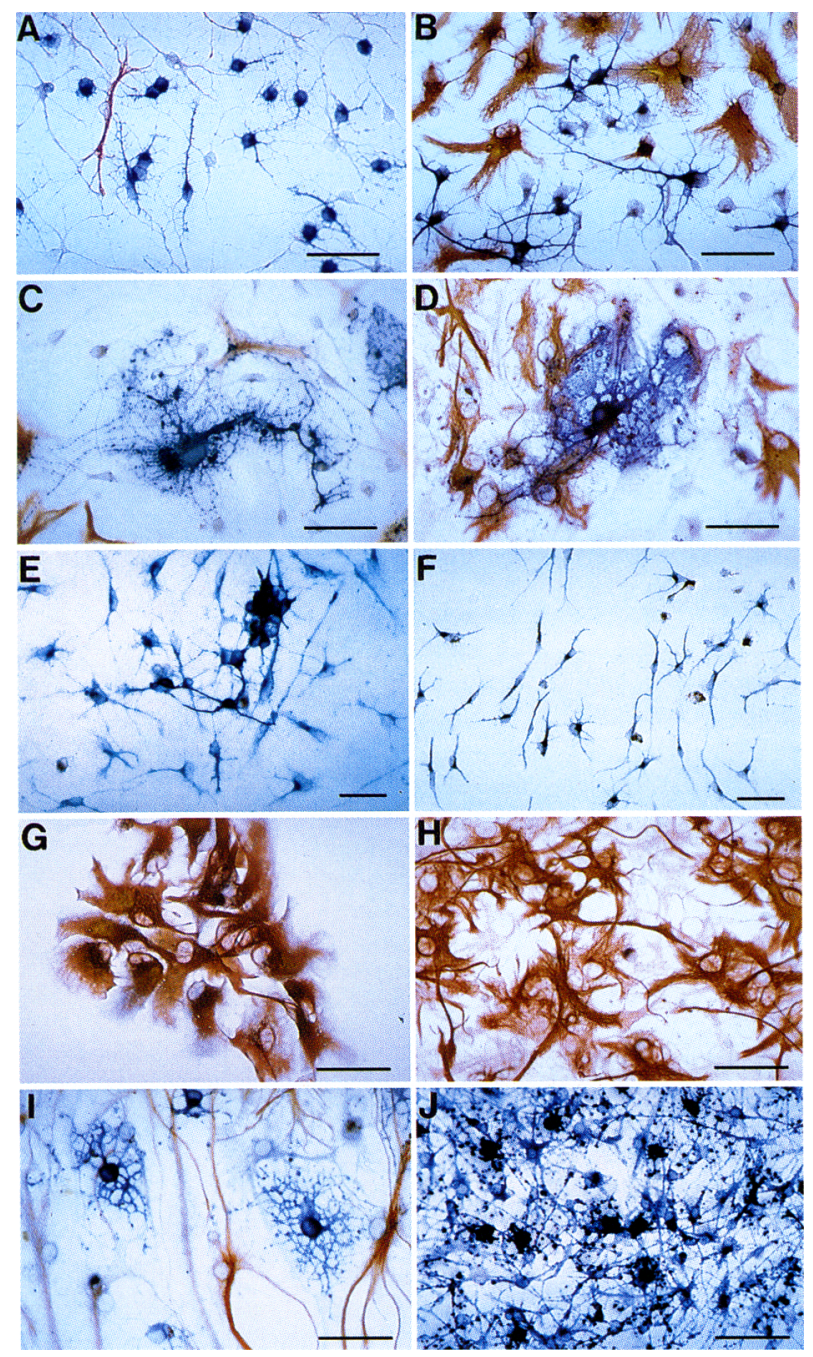

Figure 3. Demonstration of multipotentiality and influence of extracellular factors on cell-type specification. Representative clones of embryonic hippocampal cells $(A, C, E, G, I)$ and adult subependymal cells $(B, D, F, H, I)$ double-stained with combinations of antibodies to reveal different cell types within individual clones: anti-MAP2, neuronal; anti-GalC, ologodendrocytic; anti-GFAP, astrocytic. $(A, B)$ Anti-MAP2 (blue) and anti-GFAP (red). $(C, D)$ Anti-GalC (blue) and anti-GFAP (red). $(E, F)$ Clones differentiated in the presence of PDGF; anti-MAP2 (blue) and anti-GFAP (red). Most cells are MAP2 + and few are GFAP +. $(G, H)$ Clones differentiated in the presence of CNTF; antiMAP2 (blue) and anti-GFAP (red). All cells are intensely $\mathrm{GFAP}+.\{I, J \mid$ Clones differentiated in the presence of $\mathrm{T} 3$; antiGalC (blue) and anti-GFAP (red). GFAP + and, particularly, GalC + cells increased. MAP2 + cells decreased (see Table 3).

pocampus, $\sim 70 \%$ of acutely dissociated cells in highdensity culture responded to bFGF by undergoing mitosis within 2 days of plating. Clonal analysis suggests that the stem cells constitute a large fraction of the cells in the starting culture. However, the low plating efficiency at clonal density did not permit a direct estimation of the proportion of CNS stem cells in the starting culture, im-
A

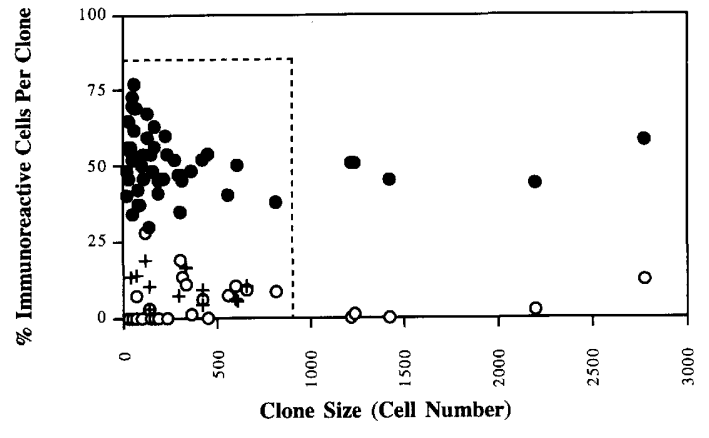

B

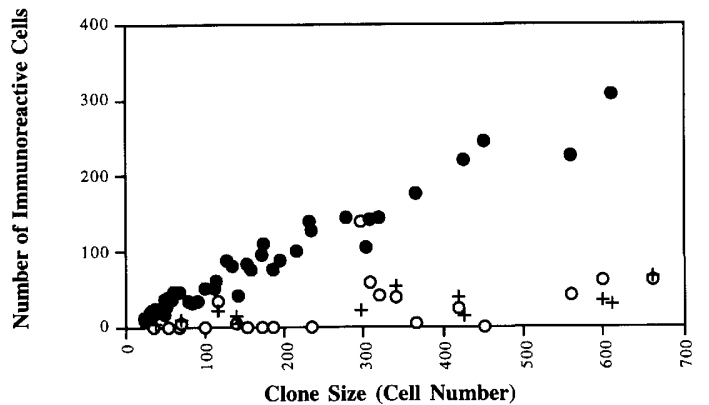

Figure 4. Proportion of multiple cell types in differentiated clones. (A) Clones of various sizes ranging from 39 cells to 2800 cells were differentiated for 6 days and analyzed for two cell types at a time by double immunohistochemistry. (O) MAP2+ neurons; $1+\mid \mathrm{GalC}+$ oligodendrocytes; $(O) \mathrm{GFAP}+$ astrocytes. A partial list of the clonal data is given in Table 1 and immunostaining shown in Fig. 3. Neuronal population constituted $50 \%$ of the clones, independent of the clone size. (B) Small clones within the area defined by a broken line in $A$ replotted to emphasize that the number of neurons increased linearly with the increasing clone size.

mediately after dissociation of the tissues. As an alternative approach, acutely dissociated E14 cortical cells were plated at high density and clonal analysis was performed by infecting mitotic cells with a replication-defective retrovirus expressing $\beta$-galactosidase with a nu-

Table 2. Retroval lineage analysis of E16 cortical cells

\begin{tabular}{llr}
\hline $\begin{array}{l}\text { Frequency of } \\
\text { clones }(\%)^{\mathrm{a}}\end{array}$ & Clonal type $^{\mathrm{b}}$ & $\begin{array}{l}\text { Average clone } \\
\text { size }(\text { cells })^{\mathrm{c}}\end{array}$ \\
\hline 44 & Multipotential & $38.3 \pm 7.3$ \\
49 & Astrocytic & $19.5 \pm 5.3$ \\
4 & Neuronal & $7.7 \pm 2.0$ \\
3 & Mixed glial & $15.0 \pm 2.0$
\end{tabular}

abed on total $68 \mathrm{X}$-gal positive clones triple-stained with antiMAP2, GFAP, and $\mathrm{O} 4$ antibodies.

${ }^{b}$ (Multipotential) mixed composition of MAP2 +, GFAP +, and / or O4 + cells and unstained cells; (astrocytic) GFAP + cells and unstained cells; (neuronal) MAP2 + cells and unstained cells; (mixed glial) mixture of GFAP + cells, O4 + cells, and unstained cells.

${ }^{\mathrm{c}}$ Average number of X-gal positive cells in a clone ( \pm S.E.M.). 
clear localization signal. Cells were differentiated by withdrawing bFGF, and the resulting cell types were identified by triple fluorescence staining with cell typespecific antibodies. Forty-four percent of the $\mathrm{X}$ gal+ clones were composed of multiple cell types, whereas $49 \%$ were astrocytic and $4 \%$ were neuronal (Table 2 ). These results show that a substantial proportion of the proliferative cells in the acutely dissociated neurcepithelium are multipotential and suggest that stem cells are abundant in the fetal brain.

\section{Stem cells in the adult CNS}

The subependymal layer of adult rat brain contains mitotic nestin-positive cells that could be expanded in aggregate culture in the presence of EGF but not bFGF (Reynolds and Weiss 1992). Cells in these aggregate cultures show neuronal and astrocytic properties. To further define the developmental capacity of proliferating nestin-positive cells in the adult brain, the mitotic population $\left(1 \%\right.$ of $1 \times 10^{5}$ cells/brain) lining the lateral ventricle of adult rat striatum was expanded in the presence of bFGF and compared with the embryonic precursors. The morphology and growth characteristics of these nestin-positive adult cells were similar to those of embryonic cells. Following bFGF withdrawal, marked clones differentiated into multiple cell types expressing MAP2, $\beta$-tubulin type III, GFAP, and GalC (Fig. 3B,D). Strikingly, the same high proportion of neurons were found in differentiated clones of adult cells as in the embryonic clones (Table 1C).

EGF was equally effective as bFGF as a mitogen for adult cells (Fig. 5), and, when these EGF-expanded clones

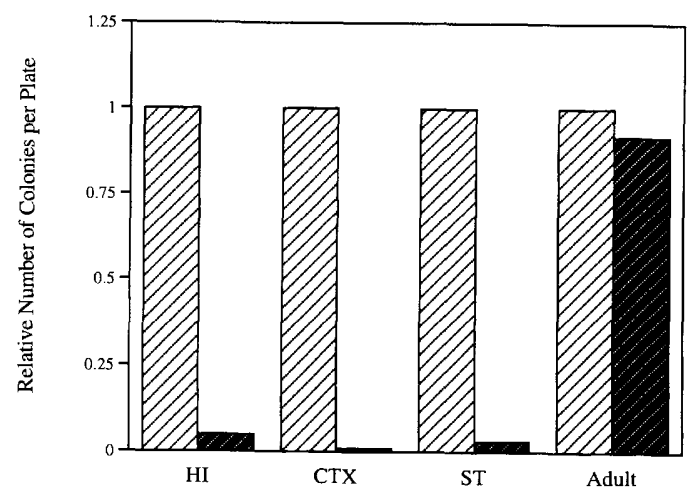

Figure 5. Distinct mitogenic efficacies of EGF and bFGF on acutely dissocated neuroepithelial cells. Cells acutely dissociated from E16 hippocampus (HI), E14 cortex (CTX) and striatum (ST), and adult subependymal layer (Adult) were plated initially at $1 \times 10^{4}$ cells per $10-\mathrm{cm}$ plate and expanded with either EGF $(20 \mathrm{ng} / \mathrm{ml})$ or bFGF $(10 \mathrm{ng} / \mathrm{ml})$. Colonies arising after 10 days of expansion were stained for nestin and counted. Relative number of colonies averaged from at least two experiments for each region are shown $(\mathrm{bFGF}=1)$. Twenty- to fiftyfold more nestin + colonies per plate were present when the embryonic cells were grown in bFGF (light hatched bars) than in EGF (dark hatched bars).
Table 3. Effects of extracellular factors on cell-type specification

\begin{tabular}{|c|c|c|c|c|}
\hline & $\begin{array}{l}\text { Untreated } \\
(\%)\end{array}$ & $\begin{array}{l}+ \text { PDGF } \\
|\%|\end{array}$ & $\begin{array}{l}+ \text { CNTF } \\
(\%)\end{array}$ & $\begin{array}{l}+\mathrm{T} 3 \\
(\%)\end{array}$ \\
\hline \multicolumn{5}{|c|}{ A. bFGF-expanded embryonic clones } \\
\hline $\mathrm{MAP} 2+$ & $45.9 \pm 2.0$ & $81.0 \pm 1.7$ & $0.9 \pm 0.1$ & $11.5 \pm 3.3$ \\
\hline tau + & N.D. & $84.4 \pm 7.0$ & N.D. & N.D. \\
\hline TuJl+ & $9.9 \pm 1.8$ & $72.4 \pm 6.2$ & N.D. & N.D. \\
\hline NF-M + & $1.0 \pm 0.2$ & $53.0 \pm 7.5$ & N.D. & N.D. \\
\hline GalC + & $7.4 \pm 2.8$ & $2.8 \pm 0.7$ & $4.5 \pm 1.2$ & $21.2 \pm 2.7$ \\
\hline GFAP + & $6.3 \pm$ & $2.0 \pm 0.7$ & $97.3 \pm 1.8$ & $20.7 \pm 7.5$ \\
\hline Dead $^{a}$ & $11.2 \pm 2.0$ & $8.8 \pm 1.4$ & $18.8 \pm 4.5$ & $11.8 \pm 1.5$ \\
\hline \multicolumn{5}{|c|}{ B. bFGF-expanded adult clones } \\
\hline $\mathrm{MAP} 2+$ & $36.8 \pm 2.7$ & $73.9 \pm 1.9$ & $11.8 \pm 2.2$ & $35.2 \pm 2.9$ \\
\hline TuJl + & $47.9 \pm 2.7$ & $72.4 \pm 7.8$ & N.D. & N.D. \\
\hline $\mathrm{GalC}+$ & $4.8 \pm 2.9$ & N.D. & N.D. & $47.4 \pm 3.6$ \\
\hline GFAP + & $20.3 \pm 2.1$ & $2.2 \pm 0.7$ & $72.9 \pm 1.9$ & $32.4 \pm 5.4$ \\
\hline \multicolumn{5}{|c|}{ C. EGF-expanded embryonic clones } \\
\hline MAP2 + & $42.0 \pm 6.5$ & $54.0 \pm 4.0$ & $9.1 \pm 2.6$ & $9.2 \pm 2.4$ \\
\hline GalC+ & & $11.1 \pm 2.9$ & $7.6 \pm 1.1$ & $14.0 \pm 1.2$ \\
\hline GFAP + & $46.4 \pm 3.1$ & $11.9 \pm 1.8$ & $83.7 \pm 3.1$ & $59.8 \pm 3.7$ \\
\hline
\end{tabular}

Clones were differentiated for 6 days either in the absence (untreated) or the presence of indicated factors: $10 \mathrm{ng} / \mathrm{ml}$ PDGF, 10 $\mathrm{ng} / \mathrm{ml} \mathrm{CNTF}$, and $10 \mathrm{~mm}$ T3. Relative proportions of immunoreactive cells per clone are shown. $n=6-23$ clones. (N.D.) Not determined. \pm S.E.M.

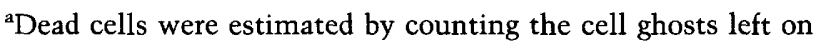
the plate (see Materials and Methods).

were differentiated, they gave rise to all three cell types. For the embryonic cells from several different regions, EGF was at least 10-fold less effective than bFGF as a mitogen for acutely dissociated cells, independent of the initial cell density. However, EGF-expanded embryonic clones also differentiated into all three cell types upon withdrawal of the mitogen (Table $3 \mathrm{C}$ ). Thus, with the exception of the proliferative effects of EGF, these data reveal that the multipotential cells from embryonic and adult CNS are remarkably similar.

\section{Influence of extracellular factors on CNS stem cells}

The clonal analysis suggests that the multipotential stem cells are not committed prior to mitogen withdrawal and that extracellular signals may regulate celltype determination. We tested whether the proportion of the cell types generated within a clone could be influenced by diffusible molecules, growth factors, and cytokines during either proliferation or differentiation. Factors were added starting from 2 days prior to bFGF withdrawal and then for 6 days in the absence of bFGF. Thus, we tested for a possible window of influence during the last 2 days of proliferation, the last mitotic cycle, and the subsequent differentiation period.

Three soluble factors, platelet-derived growth factor (PDGF), ciliary neurotrophic factor (CNTF), and triiodothyronine (T3), showed the most dramatic and contrasting effects on the differentiating clones. In embryonic clones, the proportion of cells expressing neuronal 
antigens increased significantly in the presence of PDGF-AA, PDGF-AB, or PDGF-BB during differentiation. Up to $80 \%$ of the cells were neuronal with MAP2, tau, tubulin type III, or NF-M expression. Only $2 \%$ of the cells expressed O4, GalC, or GFAP (Fig. 3E; Table 3A). The cells expressing the neuronal antigens showed a less mature morphology under these conditions and continued to proliferate.

When treated with CNTF, clones gave rise almost exclusively to astrocytes (Fig. 3G; Table 3A). Remarkably, $<1 \%$ of the cells were MAP2 + in CNTF. The CNTFtreated cells were intensely GFAP + , and all showed a flat, astrocytic morphology. Leukemia inhibitory factor (LIF) showed identical effects to CNTF. The thyroid hormone T3, influenced the differentiation of the multipotential precursors toward a mixed glial fate (Fig. 3I; Table 3A). Astrocytes and oligodendrocytes were both increased threefold, and there was a marked decrease in the proportion of neurons. As in the untreated clones, the $\mathrm{GalC}+$ and $\mathrm{O} 4+$ cells showed characteristic oligodendrocytic morphologies. The clones were of similar size in all of the experiments, and numerical analysis of dead cells showed that there was no significant change in cell death (this issue is addressed further in data shown in Table 4). Thus, selective cell death could not account for the changes in the proportion of cell types shown. Similar results were obtained with multipotential stem cells from embryonic cortex and striatum.

The multipotential cells derived from the subependymal layer of the adult brain showed quantitatively similar differentiation responses to PDGF, CNTF, and T3 (Fig. 3F,H,J, respectively; Table 3B). Moreover, embryonic CNS stem cells expanded in EGF without exposure to bFGF also responded similarly to the three factors (Table 3C). CNS stem cells from adult and several embryonic brain areas responded equivalently to the three factors, suggesting that these factors are affecting a general mechanism of cell-type specification for mammalian CNS. Thus, the effects of the differentiation factors are independent of the source of the stem cells or the mitogen used to maintain them.
Immunohistochemistry with antibodies against GABA and glutamate shows that subsets of neurons in clones express these transmitters (not shown). A recent study shows that glutamate influences the proliferation of cells derived from the fetal cortex (LaMantia 1995; LoTurco et al. 1995), raising the interesting possibility that this neurotransmitter regulates the neuronal differentiation of CNS stem cells. bFGF-expanded stem cells exposed to GABA or glutamate showed no change in their proliferation (data not shown). Although it is likely that these neurotransmitters may influence later stages of differentiation, our data suggest that they do not initiate cell cycle withdrawal nor do they influence early steps in stem-cell differentiation.

\section{Instructive action of extracellular factors}

Because the extracellular factors were tested over the entire period of cell differentiation, it was important to demonstrate unambiguously whether the factors were acting directly on proliferating stem cells or only during the period of stem-cell differentiation. Thus, actively dividing stem-cell clones were exposed to PDGF, CNTF, or T3 at the four-cell stage ( 2 days after plating) in the presence of bFGF and allowed to expand for an additional 6 days in the presence of bFGF and one of the factors. Under these conditions, PDGF has no effect on antigen expression in stem cells showing that the induction of neuronal antigens requires the removal of bFGF.

CNTF induced the expression of GFAP in $98 \%$ of the cells in the presence of bFGF (Table 4). Very few cells expressed neuronal or oligodendrocytic antigens or morphologies, and there was no significant cell death. After $24 \mathrm{hr}$ of CNTF treatment, mitotic stem-cell clones at only the four-cell stage began to undergo overt morphological transformation and express GFAP. When cultured for 6 days in bFGF and CNTF, almost all cells adopted astrocytic morphology and expressed GFAP (Table 4). The number of dead cells (Table 4) excludes the possibility that selective mechanisms account for the switch in antigen expression. These results indicate that

Table 4. Direct derivation of committed astroblasts from CNS stem cells by CNTF

\begin{tabular}{|c|c|c|c|c|c|c|}
\hline Culture experience & $\begin{array}{l}\text { Average cell } \\
\text { number } \\
\text { per clone }\end{array}$ & $\mathrm{MAP} 2+$ & $\mathrm{O} 4+/ \mathrm{GC}+$ & GFAP + & Unstained & Dead $^{a}$ \\
\hline$+\mathrm{F}$ & $213 \pm 56$ & $0 \%$ & $0 \%$ & $0 \%$ & $99.9 \pm 0.1 \%$ & $0 \%$ \\
\hline$+F+C$ & $194 \pm 36$ & $0 \%$ & $0 \%$ & $97.8 \pm 2.1 \%$ & $2.1 \pm 2.0 \%$ & $0 \%$ \\
\hline$+\mathrm{F}+\mathrm{C} \rightarrow-\mathrm{F}+\mathrm{C}$ & $235 \pm 44$ & $0 \%$ & $2.6 \pm 0.5 \%$ & $80.8 \pm 3.8 \%$ & $16.6 \pm 3.5 \%$ & $11.9 \pm 4.9 \%$ \\
\hline$+\mathrm{F}+\mathrm{C} \rightarrow+\mathrm{F}-\mathrm{C}$ & $634 \pm 140$ & $0 \%$ & $0 \%$ & $99.9 \pm 0.1 \%$ & $0 \%$ & $0 \%$ \\
\hline$+\mathrm{F}+\mathrm{C} \rightarrow+\mathrm{F}-\mathrm{C} \rightarrow-\mathrm{F}-\mathrm{C}$ & $1648 \pm 673$ & $3.6 \pm 1.1 \%$ & $8.9 \pm 1.8 \%$ & $79.9 \pm 2.9 \%$ & $11.1 \pm 1.8 \%$ & $3.7 \pm 0.9 \%$ \\
\hline$+\mathrm{F}+\mathrm{C} \rightarrow-\mathrm{F}-\mathrm{C}+\mathrm{E}$ & $775 \pm 209$ & $0 \%$ & $0 \%$ & $99.9 \pm 0.1 \%$ & $0 \%$ & $14.8 \pm 5.5 \%$ \\
\hline$+\mathrm{F}+\mathrm{C} \rightarrow-\mathrm{F}-\mathrm{C}+\mathrm{E} \rightarrow-\mathrm{F}-\mathrm{C}-\mathrm{E}$ & $1677 \pm 459$ & $0 \%$ & $7.1 \pm 1.9 \%$ & $80.5 \pm 1.8 \%$ & $12.3 \pm 2.0 \%$ & $14.2 \pm 2.1 \%$ \\
\hline
\end{tabular}

Embryonic hippocampal clones were expanded in bFGF alone ( $+\mathrm{F}$, Control) or together with $10 \mathrm{ng} / \mathrm{ml}$ CNTF for 6 days (+F + C). Arrows indicate subsequent changes in culture condition. $(-\mathrm{F}+\mathrm{C})$ Without bFGF and with CNTF alone; $(+\mathrm{F}-\mathrm{C})$ with bFGF alone; $(-\mathrm{F}-\mathrm{C})$ without either bFGF or CNTF; $(-\mathrm{F}-\mathrm{C}+\mathrm{E})$ switched to $10 \mathrm{ng} / \mathrm{ml}$ EGF alone; $(-\mathrm{F}-\mathrm{C}-\mathrm{E})$ subsequent removal of EGF. At lease six clones were counted under each condition. \pm S.E.M.

${ }^{2}$ Dead cells were estimated by counting the cell ghosts left on the plate (see Materials and Methods). 
Johe et al.

CNTF acts directly to induce GFAP in the proliferating stem cell.

To further determine whether the astrocytic differentiation is transient or a stable change in the stem cell, clones initially grown in bFGF and CNTF were further expanded for 4 additional days in bFGF alone without CNTF. The cells continued to divide, evident from the increasing clone size, and maintained the astrocytic morphology and intense GFAP expression (Table 4). Thus, the continued presence of exogenous CNTF was not required to maintain GFAP expression. But, do the GFAP + cells differentiate into astrocytes and only astrocytes? When bFGF was withdrawn from the culture, $80 \%$ of the cells continued to express GFAP intensely with the typical astrocytic morphology (Table 4). Interestingly, a fraction of the cells differentiated into $\mathrm{MAP} 2+$ or $\mathrm{O} 4+/ \mathrm{GalC}+$ cells. In the continuous presence of CNTF, expression of these antigens could be suppressed (Table 4). When the cells exposed to CNTF were treated with EGF for 4 days, the cell number per clone increased as in bFGF and almost all cells were astrocytic (Table 4). The mitogenic effects of bFGF and EGF for CNTF-treated stem cells were confirmed by BrdU double-labeling experiments (data not shown). These data demonstrate that a transient exposure to CNTF induces in the stem cell a stable fate restriction from a multipotent state to a unipotent and proliferative astroblast state.

Under the same paradigm as with CNTF, when stemcell clones were expanded in the presence of bFGF and T3 starting from the four-cell stage, some of the clones $(\sim 10 \%)$ consisted entirely of $\mathrm{O} 4+$ mitotic cells (Fig. 6A). Remaining clones contained variable proportions of $\mathrm{O} 4+$ cells as subsets within a clone. The $\mathrm{O} 4+$ cells were not distributed randomly but grouped together, suggesting that they were part of a subclone (Fig. 6B). Is the expression of $\mathrm{O} 4$ antigen a stable property for cells ex posed to T3? When clones exposed to T3 were grown subsequently for 4 days with bFGF alone without T3, clones entirely composed of $\mathrm{O} 4+$ cells with oligodendrocytic morphologies were present (Fig. 6C). In other clones, large subsets of $\mathrm{O} 4+$ cells with oligodendrocytic morphology were found clustered within a clone. The $\mathrm{O} 4+$ cells assumed more mature oligodendrocytic morphologies when bFGF was finally withdrawn (Fig. 6D). These data show that T3 exposure leads multipotent stem cells to glial lineage, where subsets of cells make a stable transition to proliferating oligodendrocytic precursors.

\section{Discussion}

A key feature of the studies presented here is that both proliferation and differentiation of the multipotential neuroepithelial stem cells can be controlled efficiently. This in vitro system permitted for the first time a quantitative analysis of the developmental capacity of CNS stem cells. Several lines of evidence indicate that most of the cells in the clones are multipotential and are not predetermined for any of the major cell types prior to mitogen withdrawal. First, the proportion of neurons generated is independent of clone size. The significance of this unchanged probability of neuronal generation is that it supports a model in which cellular properties are constant as clones expand. This stability is supported by the unchanged differentiation capacity in clones of acutely dissociated cells and in clones generated from cells that have been passaged. Second, subcloning experiments demonstrate that many multipotential secondary clones can be derived from a single primary clone, again showing that the multipotential cells are expanding in number. Asymmetric cell division may still be an im-
Figure 6. Direct derivation of committed oligodendroblast from CNS stem cells by T3. (A) A stem-cell clone expanding in the presence of both bFGF and T3, immunostained with anti-O4 antibody. Revealed by triple staining, all of the cells in this clone are $\mathrm{O} 4+, \mathrm{MAP} 2-$, and GFAP-, while they are mitotic. (B) Another stemcell clone in the presence of bFGF and T3, double-stained with anti-O4 (green) and anti-GFAP (red) antibodies. O4 + mitotic cells appeared in a confined sector within the clone. The remaining cells expressed a low level of GFAP. (C) A clone of mitotic $\mathrm{O} 4+$ cells after the $\mathrm{T} 3$ treatment continuing to expand in bFGF alone. The oligodendrocytic fate was retained throughout successive cell division in the absence of $\mathrm{T} 3$. (D) A differentiating O4 + clone, 6 days after bFGF has been finally withdrawn. Oligodendrocytes stably express $\mathrm{O} 4+$ in the absence of $\mathrm{T} 3$ and bFGF and differentiate into more mature morphologies.
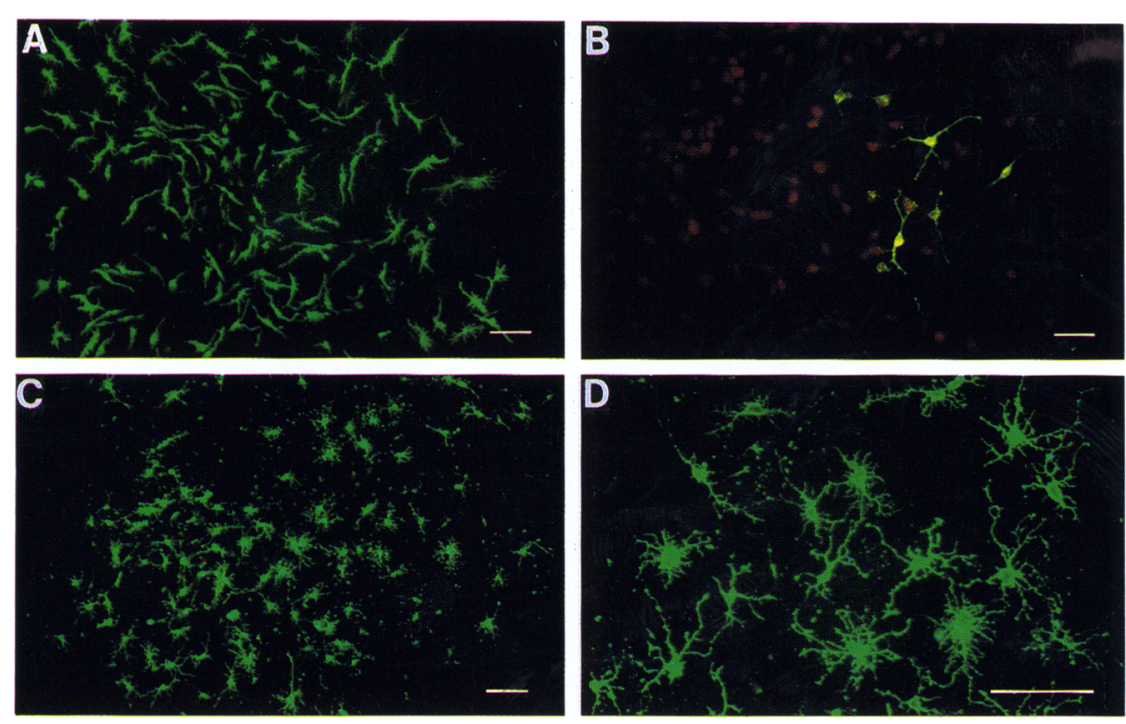
portant mechanism for cell-type specification in vivo (Chenn and McConnell 1995). However, a strict asymmetric model, in which only one of the daughter cells maintains multipotentiality, cannot account for the exponential increase in stem cells seen in culture.

Clonal analysis showed that multipotential stem cells could be isolated readily from many regions of the developing neuroepithelium. Initial plating efficiency at clonal density is inefficient. However, at high density and at short times after dissociation, a large proportion of cells survive and proliferate in response to bFGF. Almost half of the retrovirus-labeled clones in these short-term cultures are also multipotential, showing that CNS stem cells are abundant throughout the developing neuroepithelium. A model of cell-type specification that emerges from these data is that stem cells proliferate symmetrically to produce uncommitted daughter cells that form a major component of the neuroepithelium.

The distinct effects of extracellular factors acting at early stages of cell-type differentiation in the CNS are summarized in Figure 7. PDGF- $A A$, $-\mathrm{AB}$, and $-\mathrm{BB}$ increased the proportion of neuronal cells but only in the absence of bFGF. All three forms of PDGF $\{\mathrm{AA}, \mathrm{AB}$, and $\mathrm{BB})$ act in the same manner, indicating that the $\alpha$ receptor mediates this effect of the factor. The expression of the $\alpha$ receptor and lower levels of the $\beta$ receptor in cultured CNS stem cells has been established by Northern blotting (K. Forsberg-Nilsson and R. McKay, unpubl.). Stem cells treated with PDGF express several neuronal

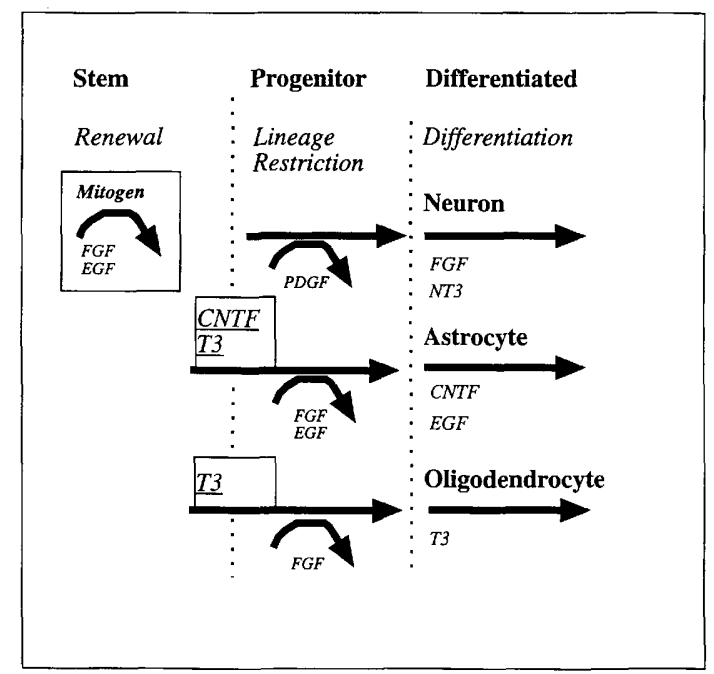

Figure 7. Cell-type transitions of CNS stem cells. This model illustrates the distinct effects of extracellular factors on CNS stem cells and the different cell types derived from stem cells. Three classes of cells are shown: multipotential stem cells, lineage restricted progenitors for neurons, astrocytes, and oligodendroctyes, and the three mature cell types. Mitogenic factors for stem and progenitor cells are shown with a bent arrow. Differentiation factors are shown next to a straight arrow. Differentiation factors of two kinds are shown: factors that promote differentiation and factors that cause lineage restriction /underlined). antigens (MAP2a, MAP2b, MAP2c; tau; Tull; and neurofilament). PDGF does not induce the expression of these antigens in the presence of bFGF. These data suggest that PDGF is not responsible for a fate choice but is a survival and proliferation factor for immature neurons.

In contrast, CNTF and T3 induce glial fates and morphologies in the presence of bFGF. Transient exposure of stem cells to CNTF or T3 is sufficient to iniate a stable switch to a glial fate. The actions of CNTF and T3 are mediated clearly by a direct, instructive mechanism. These factors and/or their receptors are known to be present and functional during CNS development (Yeh et al. 1991; Orr-Urtreger et al. 1992; Davis et al. 1993; Ip et al. 1993; Barres et al. 1994; Ware et al. 1995). There are few examples of instructive action of soluble ligands on multipotential stem cells. Recently, GGF, BMP2, and TGF- $\beta 1$ have been shown to act instructively on PNS stem cells leading to neuronal, glial, or muscle fates (Shah et al. 1994, 1996). In principle, the difference between neuronal and glial fates might require a complex extracellular code. Our data show that single growth factors can rapidly and instructively direct lineage restrictions that are then maintained in the absence of the initiating signal.

Transplantation of immortalized and primary neuroepithelial cells also shows that local signals rather than cell autonomous mechanisms direct neuronal differentiation and that these signals may be retained in the adult cerebral cortex (Renfranz et al. 1991; Brustle et al. 1995; Shihabuddin et al. 1995; Vicario-Abejon et al. 1995). Thus, data from both transplantation and tissue culture stress the importance of extracellular signals and cellular plasticity in regulating the organization of the developing and adult brain.

There is evidence from lineage analysis in vivo and in vitro for the presence of lineage restrictions, including bipotential neuronal and oligodendrocyte precursors and committed neuronal progenitors (Luskin 1993; Davis and Temple 1994; Luskin and McDermott 1994; Williams and Price 1995). The identification of the bipotential oligodendrocyte precursor cell, O-2A, from the postnatal optic nerve most directly demonstrates that restricted progenitors are produced during development (Raff et al. 1983). Stem cells may differentiate into oligodendrocytes through an intermediate stage resembling an O-2A cell. However, stem cells are distinct from the $\mathrm{O}-2 \mathrm{~A}$ cells as their origins, growth characteristics, morphology, antigenic profile, and developmental capacities differ. Most notably, stem cells efficiently give rise to neurons. We have shown previously that bFGF expanded cells differentiate in the presence of neurotrophins to express complex morphologies and antigens characteristic of specific neuronal subtypes (Vicario-Abejon et al. 1995b). Here, we show that the stem cells rapidly express receptors for excitatory and inhibitory neurotransmitters when they differentiate. In addition, electrophysiological experiments show that expanded cells form functional excitatory and inhibitory synapses (C. Vicario-Abejon, C. Collin, M. Segal, K. Johe, and R. McKay, unpubl.).

Neurons are not generated in large numbers in the 
adult mammalian CNS with the exception of the olfactory bulb (Altman 1969; Lois and Alvarez-Buylla 1992; Luskin 1993) and the hippocampal formation (Altman 1965; Cameron et al. 1993). Cultured adult precursors have been shown to differentiate into neurons and glia, but little is known about the mechanisms that regulate the differentiation of these cells (Gritti et al. 1996). Both the clonal analysis and the response to growth factors reported here show that cells derived from the adult CNS have properties that are very similar to stem cells in the fetal neuroepithelium. Further characterization of these general mechanisms that control the multipotentiality, self-renewal, and fate restriction of stem cells is clearly important to develop new therapies for cell regeneration and replacement in the adult nervous system.

\section{Materials and methods \\ Isolation, mass expansion, and differentiation of embryonic CNS stem cells}

Rat embryonic hippocampus (gestation day 16; day of conception is day 1; Taconic Farm/ was dissected in Hank's buffered saline solution (HBSS) and dissociated by brief mechanical trituration in HBSS. The cells were collected by centrifugation and resuspended in a serum-free medium containing Dulbecco's modified Eagle medium (DMEM)/F12, glucose, glutamine, sodium bicarbonate, $25 \mu \mathrm{g} / \mathrm{ml}$ of insulin, $100 \mu \mathrm{g} / \mathrm{ml}$ of human apotransferrin, $20 \mathrm{nM}$ progesterone, $100 \mu \mathrm{M}$ putrescine, $30 \mathrm{nM}$ sodium selenite (pH 7.2) (Bottenstein and Sato 1979), plus 10 $\mathrm{ng} / \mathrm{ml}$ of recombinant human bFGF (R\&D, Inc.) (Vicario-Abejon et al. 1995b). Cells $\left(1 \times 10^{6}\right)$ were plated per $10-\mathrm{cm}$ plastic tissue culture plate precoated with $15 \mu \mathrm{g} / \mathrm{ml}$ of poly-L-ornithine and 1 $\mu \mathrm{g} / \mathrm{ml}$ of bovine plasma fibronectin (GIBCO). bFGF was added daily, and media change was every 2 days. Cells were passaged at $50 \%$ confluence ( 4 days after initial plating) by briefly incubating them in HBSS and scraping with a cell scraper.

After various periods of expansion, differentiation of CNS stem cells was initiated by culturing the cells in serum-free medium without bFGF. To analyze the time course of differentiation into neurons, rapidly dividing cells were incubated for the last $24 \mathrm{hr}$ with $10 \mu \mathrm{M}$ BrdU (bromodeoxyuridine) prior to passaging. Cells were harvested by using trypsin and soybean trypsin inhibitor and plated in duplicate at $40,000 \mathrm{cells} / \mathrm{cm}^{2}$ into multiwell chamber slides (LabTek) precoated with poly-Lornithine $(15 \mathrm{mg} / \mathrm{ml})$ and fibronectin $(1 \mathrm{mg} / \mathrm{ml})$ and further cultured in serum-free medium without bFGF. At indicated times, the cells were fixed in $4 \%$ paraformaldehyde and stained first with various neuron-specific antibodies according to standard procedure, followed by postfixation and staining with monoclonal anti-BrdU antibody (Becton-Dickinson). Immunoreactive cells were counted under $400 \times$ magnification. At least five fields with total cell number $>1000$ per sample were counted. Antibody reagents used were anti-nestin antiserum (Nestin 130; M. Marvin and R.D.G. McKay, National Institutes of Health, Bethesda, MD), monoclonal anti-MAP2 (clone HM-2; Sigma), anti-tau antiserum (Sigma), monoclonal anti-NFs $\mathrm{L}$ and $\mathrm{M}$ (clones NR4 and NN18; Boehringer Mannheim), anti- $\beta$-tubulin type III (TuJl; gift of A. Frankfurter, University of Virginia, Charlottesville), monoclonal anti-GFAP (ICN), anti-GFAP antiserum (Chemicon), A2B5 (Boehringer Mannheim), O4 (gift of M. Schachner, ETH, Zurich, Switzerland), and monoclonal antigalactocerobroside (GalC; gift of M. Dubois-Dalcq, Pasteur Institute, Paris, France).
Isolation and expansion of adult CNS stem cells

Slices from forebrains of 250 -gram adult rats (10-20 per experiment) were prepared, and the subependymal region of striatum lining the lateral ventricles was cut out under microscope in oxygenated HBSS. The cells were dissociated by incubating minced tissues in oxygenated HBSS containing trypsin $(1 \mathrm{mg} /$ $\mathrm{ml})$, hyaluronidase $(0.7 \mathrm{mg} / \mathrm{ml})$, and kynurenic acid $(0.2 \mathrm{mg} / \mathrm{ml})$ for $10 \mathrm{~min}$ at room temperature. Cells were washed once in HBSS with $0.7 \mathrm{mg} / \mathrm{ml}$ of ovomucoid and $0.2 \mathrm{mg} / \mathrm{ml}$ of kynurenic acid, resuspended, and triturated in the same solution. Dissociated cells were recovered by centrifugation and cultured in the serum-free medium plus bFGF $(10 \mathrm{ng} / \mathrm{ml})$ as described for the embryonic cells.

\section{Clonal analysis}

At various passages, $\sim 200$ cells were plated per $10-\mathrm{cm}$ plate and cultured under conditions as described above for mass culture. Both embryonic and adult clones were generated under identical culture conditions. Within $24 \mathrm{hr}$ of plating when most cells had not yet divided, well-isolated single cells were marked with a $3-\mathrm{mm}$ circle (Nikon) on the bottom of the plate. Initial viability of the marked single cells was $5-10 \%$, and each plate typically yielded two to eight marked clones. The subsequent population of cells within each circle is progeny of the initial marked cell. Clones were expanded for up to 10 days $1500-2000$ cells). Differentiation of the clones was initiated by washing the plates once with HBSS and culturing in serum-free medium in the absence of bFGF. For subcloning, the clonal plates were washed and left in HBSS for $10 \mathrm{~min}$. Clones of 500-2000 cells were picked in a 50- $\mu$ l volume with an adjustable pipetter while viewing through a microscope. Each clone was replated in a $10-\mathrm{cm}$ plate, and single cells were marked and cultured as before.

After 6 days of differentiation, cell types in clones were analyzed by double-staining with combinations of antibodies that are cell type-specific and react with mutually exclusive cells: neurons $=\mathrm{MAP2}+$, tau,$+ \mathrm{TuJ} 1+, \mathrm{NF}-\mathrm{L}+$, or NF-M + ; astrocytes $=\mathrm{GFAP}+$; oligodendrocytes $=\mathrm{O} 4+$ or GalC + . Double staining was done sequentially using a commercial kit (Zymed) according to the manufacturer. The first antibody staining was developed with alkaline phosphatase reaction (blue) and the second with peroxidase reaction (red) (Zymed). For oligodendrocyte staining, cells fixed with $4 \%$ paraformaldehyde were stained first for the cell-surface antigens O4 or GalC without permeabilization.

For clonal analysis with a retrovirus, cells were dissociated from E16 rat hippocampus and plated at $1 \times 10^{5}$ to $5 \times 10^{5}$ cells per 10-cm dish. After 2 days in the presence of bFGF, cells were infected with a low-titer retrovirus encoding the Escherichia coli lacZ gene containing a nuclear localization signal. After an additional 3-5 days of expansion, cells were differentiated by bFGF withdrawal and analyzed 6 days later by X-gal reaction followed by triple immunofluorescence staining. Entire plates were reacted sequentially with cell type-specific antibodies against MAP2 (monoclonal IgG), GFAP (polyclonal; Chemicon), and $\mathrm{O} 4$ (monoclonal IgM) followed by appropriate secondary antibodies conjugated with fluorescein isothiocyanate (FITC), rhodamine, or 7-amino-4-methylcoumarin-3-acetic acid (AMCA) (Jackson Laboratory). All of the well-isolated clones with nuclear X-gal staining were individually scored for $\mathrm{MAP} 2$ + (neurons), GFAP + (astrocytes), O4 + (oligodendrocytes), and unstained (unidentified) cells.

\section{Growth factors}

The mitogenic effect of various growth factors was tested by 
their ability to substitute for bFGF in rapidly expanding cultures. Acidic FGF (aFGF), transforming grow th factor- $\alpha$ (TGF- $\alpha$ ), and EGF, each at $10 \mathrm{ng} / \mathrm{ml}$ could substitute for bFGF.

The influence of growth factors on cell-type specification was tested by adding them to the culture 2 days before the withdrawal of bFGF and during the subsequent 6 days of differentiation. Factors were added daily, and medium was changed every 2 days. At the end of the 6 days of differentiation, cell types composing individual clones were analyzed by double-immunostaining with cell type-specific antibodies as described above. Factors with significant effects were, at $10 \mathrm{ng} / \mathrm{ml}$, PDGF-AA, PDGF-BB, PDGF-AB, CNTF, LIF, and $3 \mathrm{ng} / \mathrm{ml}$ of T3. Other factors tested with no significant effect on cell-type determination were NGF, NT-3, BDNF, aFGF, TGF- $\alpha$, TGF- $\beta 1$, IL1b, IL2IL11, G-CSF, M-CSF, GM-CSF (Genetics Institute), oncostatin $M$, stem-cell factor, erythropoetin, interferon gamma, 9-cis and all-trans retinoic acid, retinyl acetate, dexamethasone, corticosterone, $\mathrm{KCl}$, glutamate, and $\gamma$-amino butyric acid.

\section{RT-PCR analysis}

Cortical CNS stem cells expanded in mass culture for 8-10 days were harvested prior to differentiation or allowed to differentiate for 6 or 12 days in serum-free medium as described above. For each time point, total RNA was extracted from $\sim 2 \times 10^{7}$ cells using Trizol (GIBCO). cDNAs were prepared and amplified by polymerase chain reaction according to standard procedures. Primers used were $\beta$-actin (nucleotides 81-649, 569 nucleotides), 5'-ATGGATGACGATATCGCTG-3' and 5'ATGAGGTAGTCTGTCAGGT-3'; NMDA-R1 (nucleotides 1897-2487, 591 nucleotides), 5'-ACCCTGTCCTCTTGCCATGTGGTTTTC-3' and 5'-ACATTCTTGATACCGAACCCATGTC-3'; NMDA-R2B (nucleotides 3011-3504, 494 nucleotides), 5'-ATGACTGTGACAACCCACCCTTT-3' and 5'-ACTGACCGAATCTCGCTTGAAGT-3'; NMDA-R2C (nucleotides 1458-1798, 362 nucleotides), 5'-AACGGCAAACACGGCAAGAG-3' and 5'-CCAATGGTGAAAGATGGTCCAC-3'; GA$\mathrm{BA}_{\mathrm{A}} \alpha 5$ (nucleotides 631-936, 306 nucleotides), 5'-GTCTCCCTCTCAACAACCTTCTTG-3' and 5'-CATCTTCTGCCACCACCACAG-3'; GABA ${ }_{A} \beta 1$ (nucleotides 1096-1547, 452 nucleotides), 5'-GAGCGAGCAAACAAGACCAGAG-3' and 5'ACAAGCGAGGAGGAAAGGAGTC-3'; GAD $_{65}$ (nucleotides 713-1085, 391 nucleotides) , 5'-TCTTTTCTCCTGGTGGTGCC-3' and 5'-CCCCAAGCAGCATCCACAT-3' (Bochet et al. 1994).

\section{Acknowledgments}

We thank Drs. Shigeo Okabe, Carlos Vicario, and Oliver Brüstle for their advice; Bechien Wu for assistance with PCR; Drs. Monique Dubois-Dalcq, Melitta Schachner, Anthony Frankfurter, and Piers Emson for gifts of antibodies; and Regeneron, Inc. for neurotrophins and CNTF. T.M. was supported in part by the Deutsche Forschung Gemeinschaft.

The publication costs of this article were defrayed in part by payment of page charges. This article must therefore be hereby marked "advertisement" in accordance with 18 USC section 1734 solely to indicate this fact.

\section{References}

Altman J. 1965. Autoradiographic evidence of postnatal neurogenesis in rats. I. Comp. Neurol. 124: 319-336.

- 1969. Autoradiographic and histologic studies of postnatal neurogenesis. IV. Cell proliferation and migration in the anterior forebrain with special reference to persisting neurogenesis in the olfactory bulb. I. Comp. Neurol. 137: 433-458.

Barres, B. and M. Raff. 1994. Control of oligodendrocyte number in the developing rat optic nerve. Neuron 12: 935-942.

Barres, B.A., M.A. Lazar, and M.C. Raff. 1994. A novel role for thyroid hormone, glucocorticoids and retinoic acid in timing oligodendrocyte development. Development 120: 10971108.

Bochet, P., E. Audinat, B. Lambolez, F. Crepel, J. Rossier, M. Iino, K. Tsuzuki, and S. Ozawa. 1994. Subunit composition at the single-cell level explains functional properties of a glutamate-gated channel. Neuron 12: 383-388.

Bottenstein, J.E. and G.H. Sato. 1979. Growth of a rat neuroblastoma cell line in serum-free supplemented medium. Proc. Natl. Acad. Sci. 76: 514-517.

Brustle, O., U. Maskos, and R.D.G. McKay. 1995. Host-guided migration allows targeted introduction of neurons into the embryonic brain. Neuron 15: 1275-1285.

Cameron, H.A., C.S. Woolley, B.S. McEwen, and E. Gould. 1993. Differentiation of newly born neurons and glia in the dentate gyrus of the adult rat. Neuroscience 56: 337-344.

Chenn, A. and S.K. McConnell. 1995. Cleavage orientation and the asymmetric inheritance of Notchl immunoreactivity in mammalian neurogenesis. Cell 82: 631-641.

Davis, A.A. and S. Temple. 1994. A self-renewing multipotential stem cell in embryonic rat cerebral cortex. Nature 372: 263-266.

Davis, S., T.H. Aldrich, N. Stahl, L. Pan, T. Taga, T. Kishimoto, N.Y. Ip, and G.D. Yancopoulos. 1993. LIFR beta and gp 130 as heterodimerizing signal transducers of the tripartite CNTF receptor. Science 260: 1805-1808.

Ferri, R.T. and P. Levitt. 1995. Regulation of regional differences in the differentiation of cerebral cortical neurons by EGF family-matrix interactions. Development 121: 1151-1160.

Fishell, G. 1995. Striatal precursors adopt cortical identities in response to local cues. Development 121: 803-812.

Gage, F.H., J. Ray, and L.J. Fisher. 1995. Isolation, characterization, and use of stem cells from the CNS. Annu. Rev. Neurosci. 18: 159-192.

Galileo, D.S., G.E. Gray, G.C. Owens, J. Majors, and J.R. Sanes. 1990. Neurons and glia arise from a common progenitor in chicken optic tectum: Demonstration with two retroviruses and cell type-specific antibodies. Proc. Natl. Acad. Sci. 87: 458-462.

Gotz, M., B.P. Williams, J. Bolz, and J. Price. 1995. The specification of neuronal fate: A common precursor for neurotransmitter subtypes in the rat cerebral cortex in vitro. Eur. $J$. Neurosci. 7: 889-898.

Gritti, A., E.A. Parati, L. Cova, P. Frolichstahl, R. Galli, E. Wanke, L. Faravelli, D.J. Morasutti, F. Roisen, D.D. Nickel, and A.L. Vescovi. 1996. Multipotential stem cells from the adult mouse brain proliferate and self-renew in response to basic fibroblast growth factor. $I$. Neurosci. 16: 1091-1100.

Holt, C.E., T.W. Bertsch, H.M. Ellis, and W.A. Harris. 1988. Cellular determination in the Xenopus retina is independent of lineage and birth date. Neuron 1: 15-26.

Ip, N.Y., J. McClain, N.X. Barrezueta, T.H. Aldrich, L. Pan, Y. Li, S.J. Wiegand, B. Friedman, S. Davis, and G.D. Yancopoulos. 1993. The alpha component of the CNTF receptor is required for signaling and defines potential CNTF targets in the adult and during development. Neuron 10: 89-102.

Jacobson, M. 1991. Developmental neurobiology, 3rd ed. Plenum Press, New York, NY.

Kilpatrick, T.J., L.J. Richards, and P.F. Bartlett. 1995. The regulation of neural precursor cells within the mammalian brain. 
Mol. Cell. Neurosci. 6: 2-15.

Kornack, D. and P. Rakic. 1995. Radial and horizontal deployment of clonally related cells in the primate neocortex: Relationship to distinct mitotic lineages. Neuron 15: 311-321.

LaMantia, A.S. 1995. The usual suspects: GABA and glutamate may regulate proliferation in the neocortex. Neuron 15: 1223-1225.

Laurie, D.J., P.H. Seeburg, and W. Wisden. 1992. The distribution of 13 GABAA receptor subunit mRNAs in the rat brain. II. Olfactory bulb and cerebellum. I. Neurosci. 12: 10631076.

Lendahl, U., L.B. Zimmerman, and R.D. McKay. 1990. CNS stem cells express a new class of intermediate filament protein. Cell 60: 585-595.

Lillien, L. 1995. Changes in retinal cell fate induced by overexpression of EGF receptor. Nature 377: 158-162.

Lois, C. and A. Alvarez-Buylla. 1992. Proliferating subventricular zone cells in the adult mammalian forebrain can differentiate into neurons and glia. Proc. Natl. Acad. Sci. 90: 2074-2077.

LoTurco, J.J., D.F. Owens, M.J.S. Heath, M.B.E. Davis, and A.R. Kriegstein. 1995. GABA and glutamate depolarize cortical progenitor cells and inhibit DNA synthesis. Neuron 15: $1287-1298$.

Luskin, M.B. 1993. Restricted proliferation and migration of postnatally generated neurons derived from the forebrain subventricular zone. Neuron 11: 173-189.

- 1994. Neuronal cell lineage in the vertebrate central nervous system. FASEB I. 8: 722-730.

Luskin, M.B. and K. McDermott. 1994. Divergent lineages for oligodendrocytes and astrocytes originating in the neonatal forebrain subventricular zone. Glia 11: 211-226.

Luskin, M.B., J.G. Parnavelas, and J.A. Barfield. 1993. Neurons, astrocytes, and oligodendrocytes of the rat cerebral cortex originate from separate progenitor cells: An ultrastructural analysis of clonally related cells. I. Neurosci. 13: 1730-1750.

Mione, M.C., C. Danevic, P. Boardman, B. Harris, and J.G. Parnavelas. 1994. Lineage analysis reveals neurotransmitter (GABA or glutamate) but not calcium-binding protein homogeneity in clonally related cortical neurons. I. Neurosci. 14: $107-123$.

Monyer, H., N. Burnashev, D.J. Laurie, B. Sakmann, and P.H. Seeburg. 1994. Developmental and regional expression in the rat brain and functional properties of four NMDA receptors. Neuron 12: 529-540.

Orr-Urtreger, A., M.T. Bedford, M.S. Do, L. Eisenbach, and P. Lonai. 1992. Developmental expression of the alpha receptor for platelet-derived growth factor, which is deleted in the embryonic lethal Patch mutation. Development 115: 289303.

Parnavelas, J.G., J.A. Barfield, E. Franke, and M.B. Luskin. 1991. Separate progenitor cells give rise to pyramidal and nonpyramidal neurons in the rat telencephalon. Cereb. Cortex 1: 463-468.

Price, J. and L. Thurlow. 1988. Cell lineage in the rat cerebral cortex: A study using retroviral-mediated gene transfer. Development 104: 473-482.

Raff, M.C., R.H. Miller, and M. Noble. 1983. A glial progenitor cell that develops in vitro into an astrocyte or an oligodendrocyte depending on culture medium. Nature 303: 390396.

Reid, C.B., I. Liang, and C. Walsh. 1995. Systematic widespread clonal organization in cerebral cortex. Neuron 15: 299-310.

Renfranz P., M. Cunningham, and R.D.G. McKay. 1991. Region-specific differentiation of the hippocampal stem cell line HiB5 upon implantation into the developing mamma- lian brain. Cell 66: 713-729.

Reynolds, B.A. and S. Weiss. 1992. Generation of neurons and astrocytes from isolated cells of the adult mammalian central nervous system. Science 255: 1707-1710.

Shah, N.M., M.A. Marchionni, I. Isaacs, P. Stroobant, and D.J. Anderson. 1994. Glial growth factor restricts mammalian neural crest stem cells to a glial fate. Cell 77: 349-360.

Shah, N.M., A.K. Groves, and D.J. Anderson. 1996. Alternative neural crest cell fates are instructively promoted by TGF $\beta$ superfamily members. Cell 85: 331-343.

Shihabuddin, L.S., J.A. Hertz, V.R. Holets, and S.R. Whittemore. 1995. The adult CNS retains the potential to direct regionspecific differentiation of a transplanted neuronal precursor cell line. J. Neurosci. 15: 6666-6678.

Soriano, E., N. Dumesnil, C. Auladell, M. Cohen-Tannoudji, and C. Sotelo. 1995. Molecular heterogeneity of progenitors and radial migration in the developing cerebral cortex revealed by transgene expression. Proc. Natl. Acad. Sci. 92: 11676-11680.

Temple, S. 1989. Division and differentiation of isolated CNS blast cells in microculture. Nature 340: 471-473.

Temple, S. and X. Qian. 1996. Vertebrate neural progenitor cells: Subtypes and regulation. Curr. Opin. Neurobiol. 6: 11-17.

Turner, D.L. and C.L. Cepko. 1987. A common progenitor for neurons and glia persists in rat retina late in development. Nature 328: 131-136.

Vicario-Abejon, C., M.G. Cunningham, and R.D. McKay. 1995a Cerebellar precursors transplanted to the neonatal dentate gyrus express features characteristic of hippocampal neurons. J. Neurosci. 15: 6351-6363.

Vicario-Abejon, C., K.K. Johe, T.G. Hazel, D. Collazo, and R.D. McKay. 1995b. Functions of basic fibroblast growth factor and neurotrophins in the differentiation of hippocampal neurons. Neuron 15: 105-114.

Walsh, C. and C.L. Cepko. 1988. Clonally related cortical cells show several migration patterns. Science 241: 1342-1345.

- 1992. Widespread dispersion of neuronal clones across functional regions of the cerebral cortex. Science 255: 434440.

Ware, C., M. Horowitz, B. Renshaw, J. Hunt, D. Liggitt, S. Koblar, B. Gliniak, H. McKenna, T. Papayannopoulou, B. Thoma, L. Cheng, P. Donovan, J. Peschon, P. Bartlett, C. Willis, B. Wright, M. Carpenter, B. Davison, and D. Gearing. 1995. Targeted disruption of the low-affinity leukemia inhibitory factor receptor gene causes placental, skeletal, neural and metabolic defects and results in perinatal death. Development 121: 1283-1299.

Wetts, R. and S.E. Fraser. 1988. Multipotent precursors can give rise to all major cell types of the frog retina. Science 239: 1142-1145.

Williams, B.P. and J. Price. 1995. Evidence for multiple precursor cell types in the embryonic rat cerebral cortex. Neuron 14: 1181-1188.

Williams, B.P., J. Read, and J. Price. 1991. The generation of neurons and oligodendrocytes from a common precursor cell. Neuron 7: 685-693.

Yeh, H.-J., K.G. Ruit, Y.-X. Wang, W.C. Parks, W.D. Snider, and T.F. Deuel. 1991. PDGF A-chain gene is expressed by mammalian neurons during development and in maturity. Cell 64: 209-216

Yeh, H.-J., I. Silos-Santiago, Y.-X. Wang, R.J. George, W.D. Snider, and T.F. Deuel. 1993. Developmental expression of the platelet-derived growth factor $\alpha$-receptor gene in mammalian central nervous system. Proc. Natl. Acad. Sci. 90: 1952-1956. 


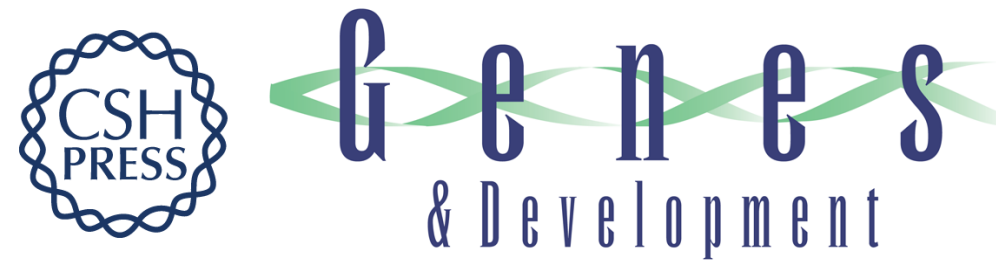

\section{Single factors direct the differentiation of stem cells from the fetal and adult central nervous system.}

K K Johe, T G Hazel, T Muller, et al.

Genes Dev. 1996, 10:

Access the most recent version at doi:10.1101/gad.10.24.3129

References This article cites 57 articles, 21 of which can be accessed free at:

http://genesdev.cshlp.org/content/10/24/3129.full.html\#ref-list-1

License

Email Alerting

Service

Receive free email alerts when new articles cite this article - sign up in the box at the top right corner of the article or click here.

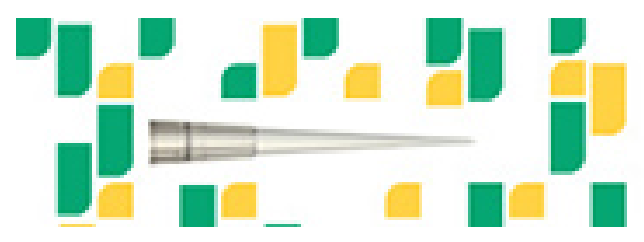

Focused on your science. 